\title{
Atmospheric distribution of polychlorinated dibenzo-p-dioxins, dibenzofurans and dioxin-like polychlorinated biphenyls around a steel plant Area, Northeast China
}

\author{
Yingming $\mathrm{Li}^{\mathrm{a}}$, Pu Wang ${ }^{\mathrm{a}}$, Lei Ding ${ }^{\mathrm{a}}$, Xiaomin $\mathrm{Li}^{\mathrm{a}}$, Thanh Wang ${ }^{\mathrm{a}}$, Qinghua Zhang ${ }^{\mathrm{a}, *}$, \\ Hongbiao Yang ${ }^{b}$, Guibin Jiang ${ }^{a}$, Fusheng Wei $^{c}$ \\ a State Key Laboratory of Environmental Chemistry and Ecotoxicology, Research Center for Eco-Environmental Sciences, Chinese Academy of Sciences, P.O. Box 2871, \\ Beijing 100085, China \\ ${ }^{\mathrm{b}}$ Anshan Environmental Monitoring Center, Anshan 114104, China

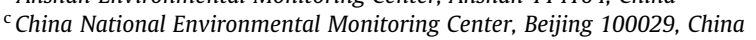

\section{A R T I C L E I N F O}

\section{Article history:}

Received 3 November 2009

Received in revised form 26 January 2010

Accepted 27 January 2010

Available online 21 February 2010

\section{Keywords:}

PCDD/Fs

Dioxin-like PCBs

Ambient air

Steel plant

Northeast China

\begin{abstract}
A B S T R A C T
Air monitoring of polychlorinated dibenzo-p-dioxins (PCDDs), polychlorinated dibenzofurans (PCDFs), and dioxin-like polychlorinated biphenyls (PCBs) was carried out in June 2008 and January 2009 to investigate the concentrations, profiles and estimating potential inhalation risks to the local residents around a steel plant area in northeast China. The air concentrations and WHO-TEQs of PCDD/Fs ranged 94$4944 \mathrm{fg} \mathrm{m}^{-3}$ (average $1352 \mathrm{fg} \mathrm{m}^{-3}$ ) and $3-247 \mathrm{fg} \mathrm{m}^{-3}$ (average $81 \mathrm{fg} \mathrm{m}^{-3}$ ), respectively. The WHO-TEQ concentrations of dioxin-like PCBs ranged $1-18 \mathrm{fg} \mathrm{m}^{-3}$ (average $5 \mathrm{fg} \mathrm{m}^{-3}$ ), contributing to 3.6-26\% of the total TEQ. Higher PCDD/F concentrations were observed in the winter, whereas higher dioxin-like PCB concentrations were found in the summer. The seasonal trend can be related to the significant correlation between the concentrations of dioxins and the reciprocal of temperature (positive for PCDD/Fs, $P<0.01$; negative for dioxin-like PCBs, $P=0.05)$. A significant positive correlation $(P<0.0001)$ was found between the concentration of total suspended particulate (TSP) and PCDD/F concentrations, but not for PCB congeners. Although the steel plant sites showed higher dioxin levels than the residential and background areas, the PCDD/F levels in the atmosphere of the steel plant area was at a relatively low level. The results from this study provides further aid in evaluating the impact of steel plants as PCDD/Fs emission sources to the ambient air in China.
\end{abstract}

Crown Copyright @ 2010 Published by Elsevier Ltd. All rights reserved.

\section{Introduction}

The Chinese government has developed the National Implementation Plan (NIP) on persistent organic pollutants (POPs) in order to implement the Stockholm Convention that was ratified by Chinese government in 2004. The NIP project includes four categories of POPs: pesticides, stockpiles, polychlorinated biphenyls (PCBs) and unintentionally produced POPs (Zhu et al., 2008). The last inventory of POPs, which refers to polychlorinated dibenzo$p$-dioxins and polychlorinated dibenzofurans ( $\mathrm{PCDD} / \mathrm{Fs}$ ), covers a large variety of emission sources associated with anthropogenic activities (UNEP, 2001).

Municipal solid waste incineration (MSWI) and production of iron and steel (e.g. iron ore sintering) are both considered as significant PCDD/F sources emitted to the environment (Anderson and Fisher, 2002; Quaß et al., 2004; Aries et al., 2006). Quaß et al.

\footnotetext{
* Corresponding author. Tel./fax: +86 1062849818.

E-mail address: qhzhang@rcees.ac.cn (Q. Zhang).
}

(2000) reported that the largest annual PCDD/Fs emission at the European scale was assessed to be released from MSWI, closely followed by emissions from iron ore sintering. In China, however, PCDD/F emissions from non-ferrous production (2.6-3389.8 g TEQ) were estimated to be much higher than that from MSWI ( $66.9 \mathrm{~g}$ TEQ if using $10 \%$ incineration ratio) due to the large quantity of iron and steel production $\left(1.97 \times 10^{8} \mathrm{ty}^{-1}\right.$ in 2002) and the low incineration ratio of municipal waste (only $4.90 \%$ until 2003) (Zhu et al., 2008). Therefore, more attention should be paid to the PCDD/Fs emissions from steel plants and their potential impact to the ambient environment in China.

Recent studies on PCDD/Fs in China have been focused on the atmospheric $\mathrm{PCDD} / \mathrm{F}$ concentrations in Chinese urban areas to evaluate the impact of PCDD/Fs to the local residents. For example, Yu et al. (2006), Li et al. (2008a,b) have reported the concentrations of PCDD/Fs in the ambient atmosphere of Guangzhou, Beijing and Shanghai city, respectively. Their results demonstrated that the levels were comparable or slightly higher than those of many other urban cities around the world. Xu et al. (2009) reported the air 
concentrations of PCDD/Fs near a MSWI in eastern China and found that the MSWI might not be the dominant dioxin source in the local area. To our knowledge, however, no research has yet to be conducted on atmospheric PCDD/Fs around steel plants in mainland China. Furthermore, studies on atmospheric dioxin-like PCBs have been rarely reported for Chinese cities.

During 2008-2009, a project was carried out to investigate the distributions of atmospheric persistent organic pollutants and their potential impact on the ambient environment around a large iron and steel plant in Anshan city, northeast China. The plant is one of the largest iron and steel plants in China, with a long production history of over 50 years and has an annual iron and steel production capacity of 32 million tons. In this work, we report the concentrations, profiles and seasonal variation of the seventeen 2,3,7,8PCDD/Fs and the twelve dioxin-like PCBs in the ambient air around the steel plant in winter and summer. Besides the steel plant zone, sampling was also conducted at urban, residential and background areas to evaluate the impact of steel plant as a PCDD/Fs source to the ambient air and their potential risks to the local residents.

\section{Materials and methods}

\subsection{Sample collection}

A total of 23 air samples were collected using high volume air samplers (GPS-1, Thermo Environmental Instruments, Inc., Franklin, MA) over a duration of $24 \mathrm{~h}$ on June 24-27th 2008 and January 12-17th 2009 around the Anshan Iron and Steel Corporation located in Anshan city, northeast China. Anshan is one of the most important iron and steel industrial bases in China and is known as "the capital of iron and steel". It is subject to warm continental monsoon climate. The average temperature is $-7.4^{\circ} \mathrm{C}$ in winter and $23.5^{\circ} \mathrm{C}$ in summer. Sampling sites S1 $\left(112^{\circ} 59.240 \mathrm{E}\right.$, $\left.41^{\circ} 08.014 \mathrm{~N}\right), \mathrm{S} 2\left(123^{\circ} 00.275 \mathrm{E}, 4^{\circ} 08.943 \mathrm{~N}\right)$ and S3 $\left(122^{\circ} 57.907 \mathrm{E}\right.$, $41^{\circ} 08.370 \mathrm{~N}$ ) were situated in the steel plant area, where iron and steel production was expected to be the main PCDD/F source to the ambient air. To better understand the impact of steel production as dioxin sources to the ambient environment, an urban site S4 $\left(122^{\circ} 56.068 \mathrm{E}, 41^{\circ} 04.974 \mathrm{~N}\right)$ was selected in the vicinity of the steel plant, $\sim 7 \mathrm{~km}$ away in the southwest of S1. Site S5 $\left(123^{\circ} 02.636 \mathrm{E}, 41^{\circ} 07.200 \mathrm{~N}\right)$ and $\mathrm{S} 6\left(123^{\circ} 07.876 \mathrm{E}, 41^{\circ} 01.509 \mathrm{~N}\right)$ were located at a residential and background area, respectively. Details of the location of sampling sites are shown in Fig. 1.

The sampling process was conducted according to the revised US EPA method TO 9A (US EPA, 1999a). Glass fiber filters (GFF,
$10.16 \mathrm{~cm}$ diameter) and polyurethane foam (PUF, $6.3 \mathrm{~cm}$ diameter, $7.6 \mathrm{~cm}$ length) materials were used to absorb particle-bound and gaseous chemicals, respectively. Prior to sampling, the GFFs were baked at $450{ }^{\circ} \mathrm{C}$ to remove organic contaminants and the PUFs were extracted with acetone in an accelerated solvent extraction (ASE) apparatus (Dionex 300; pressure, 1500 psi; temperature, $100{ }^{\circ} \mathrm{C}$; heating, $5 \mathrm{~min}$; static, $8 \mathrm{~min}$; flushing, $60 \mathrm{vol} . \%$; purge, $120 \mathrm{~s} ; 2$ cycles), followed by another ASE extraction with hexane. The sampling cartridges were vacuum-dried in desiccators and stored in sealed bags. The GFFs were weighed after equilibrating for $48 \mathrm{~h}$ in a desiccator before and after sampling to obtain the concentrations of total suspended particulate (TSP). Detailed sampling procedure has been described previously (Li et al., 2008a).

\subsection{Sample analysis}

Analysis of the seventeen 2,3,7,8-PCDD/Fs and twelve dioxin-like PCBs was in accordance with the US EPA Method 1613B (US EPA, 1997) and US EPA Method 1668A (US EPA, 1999b), respectively. Briefly, 1 ng of ${ }^{13} \mathrm{C}_{12}$-labeled surrogate standards of PCDD/Fs and PCBs (Wellington Laboratories, Canada)) were spiked into the air samples before an ASE extraction with organic solvents (hexane: dichloromethane $=1: 1$ ). The extracts were concentrated by a rotary evaporator (Heidolph, Germany) and followed by a cleanup with acid silica gel and multilayer silica columns. The final extract was spiked with $1 \mathrm{ng}{ }^{13} \mathrm{C}_{12}$-labeled injection standards of PCDD/Fs and PCBs for recovery quantification prior to the injection into a high resolution gas chromatograph and high resolution mass spectrometer (HRGC/HRMS) equipped with a $60 \mathrm{~m}$ DB-5MS column.

The HRMS (Micromass Autospec Ultima, Waters, UK) was operated in electron impact ionization (EI) and selective ion monitoring (SIM) mode at $R \geqslant 10000$. Exactly $1 \mu \mathrm{L}$ of sample solution was injected with a CTC PAL auto-sampler in splitless mode. Helium served as the carrier gas with a constant flow of $1.2 \mathrm{~mL} \mathrm{~min}^{-1}$. The electron emission energy was set to $35 \mathrm{eV}$, and the source temperature was $270^{\circ} \mathrm{C}$. Oven temperature program was employed as follows: start $160{ }^{\circ} \mathrm{C}$ held for $2 \mathrm{~min}, 160-220^{\circ} \mathrm{C}$ at $7.5^{\circ} \mathrm{C} \mathrm{min}{ }^{-1}$ held for $16 \mathrm{~min}, 220-235^{\circ} \mathrm{C}$ at $5^{\circ} \mathrm{C} \mathrm{min}^{-1}$ held for $7 \mathrm{~min}, 235-$ $330^{\circ} \mathrm{C}$ at $5^{\circ} \mathrm{C} \mathrm{min}^{-1}$ held for $1 \mathrm{~min}$.

\subsection{Quality assurance/quality control (QA/QC)}

A breakthrough test was performed by using a second PUF in series with the first PUF and no breakthrough was found. Field and laboratory blanks were routinely analyzed and values were
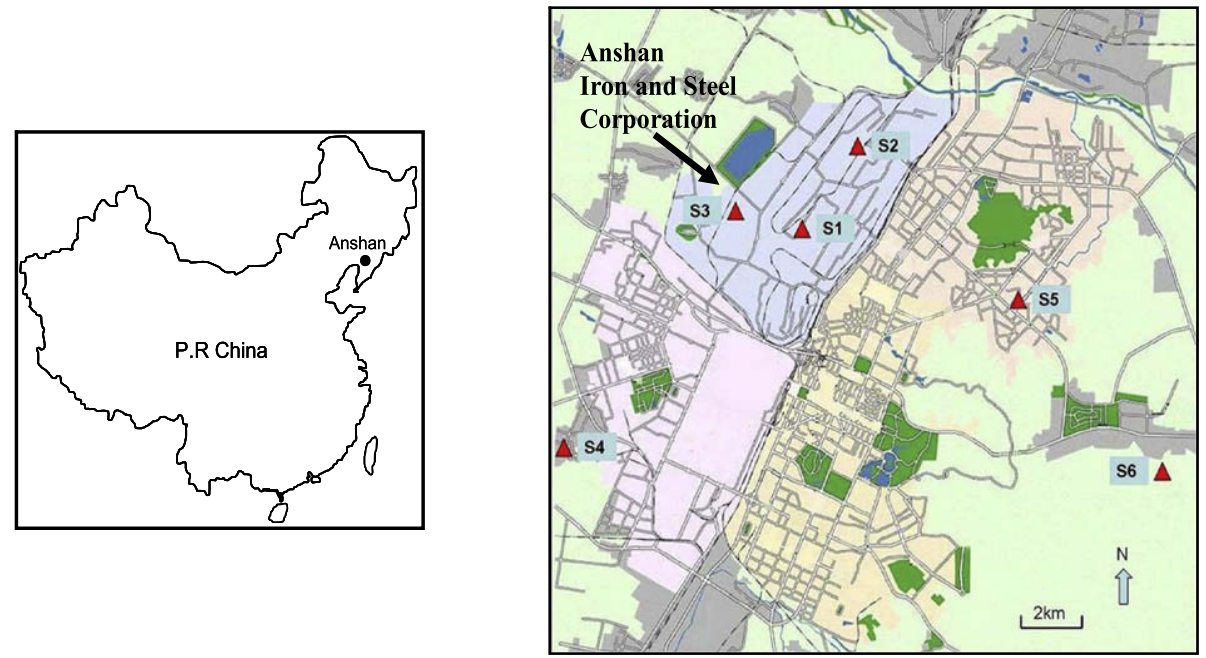

Fig. 1. Sampling location for the six monitoring sites. 
below detection limits (LOD). Sample recoveries $(n=23)$ in this study varied between $41 \%$ and $114 \%$ for PCDD/Fs and $49-147 \%$ for dioxin-like PCBs, respectively, which satisfied the limit of Method 1613B and 1668A. Our lab participated in the Tenth Round of the International Intercalibration Study (Van Bavel, 2005), which also guaranteed the analytical method used in this work. The LOD was defined as three times of the signal/noise ratio and were 6-68 $\mathrm{fg} \mathrm{m}^{-3}$ for $\mathrm{Cl}_{1-7} \mathrm{DD} / \mathrm{Fs}, 9-246 \mathrm{fg} \mathrm{m}^{-3}$ for OCDD/F, and $2-17 \mathrm{fg} \mathrm{m}^{-3}$ for the twelve dioxin-like PCBs. Detailed sample recoveries and detection limits are listed in Table S1 of the supplementary material.

\section{Results and discussion}

\subsection{Air concentration of 2,3,7,8-PCDD/Fs and dioxin-like PCBs}

All of the measured concentrations and toxicity equivalents (TEQs) are reported in Table S2-S5 of the supplementary material and summarized in Table 1 . In the case of values below the LOD, their concentrations were set as zero, i.e. not detected. The air concentrations and WHO-TEQs of PCDD/Fs ranged 94-4944 $\mathrm{fg} \mathrm{m}^{-3}$ (average $1352 \mathrm{fg} \mathrm{m}^{-3}$ ) and $3-247 \mathrm{fg} \mathrm{m}^{-3}$ (average $81 \mathrm{fg} \mathrm{m}^{-3}$ ), respectively. These results are lower than the ambient air standard of $600 \mathrm{fg} \mathrm{TEQ}^{-3}$ for dioxins proposed by Japan (Government of Japan, 2005). Of the six sampling sites, the steel plant sites S1, S2 and S3 showed relatively higher atmospheric PCDD/Fs levels

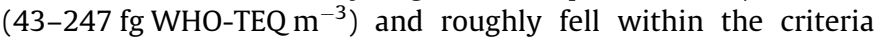
category of global urban areas $\left(100-400 \mathrm{fg} \mathrm{TEQ} \mathrm{m}^{-3}\right.$ ) reported by Lohmann and Jones (2000a), but lower than that of point sources (350-1600 fg TEQ $\mathrm{m}^{-3}$ ) (Fiedler, 1996). In comparison, the residential site S5 and background site S6 exhibited even lower PCDD/F levels and fell in the category of global rural and remote area, respectively. The PCDD/F levels in all the sampling sites were lower than other Chinese cities, including Beijing (18-644 fg I-TEQ $\mathrm{m}^{-3}$ )

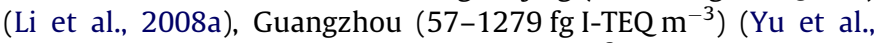
2006) and Shanghai (2.2-20 $760 \mathrm{fg} \mathrm{I-TEQ}^{-3}$ ) (Li et al., 2008b). We also compared the PCDD/F concentrations in this study with other urban cities around the world and found that it was comparable or slightly lower than those in Asian cities including Hong Kong (18-430 $\mathrm{fg} \mathrm{I}^{-T E Q ~ \mathrm{~m}^{-3}}$ ) (Sin et al., 2002), Taiwan (56$348 \mathrm{fg} \mathrm{I}^{-T E Q ~ \mathrm{~m}^{-3}}$ ) (Chang et al., 2003), Korea (169-882 fg ITEQ $\mathrm{m}^{-3}$ ) (Park and Kim, 2002) and Japan (83-550 fg I-TEQ $\mathrm{m}^{-3}$ )
(Government of Japan, 2005), but consistent with those of the European countries and United States (Greece 40-119 fg ITEQ $\mathrm{m}^{-3}$ (Kouimtzis et al., 2002); Manchester 26-220 fg I-TEQ $\mathrm{m}^{-3}$ (Lohmann et al., 2000b); London 62-180 fg I-TEQ m $^{-3}$ (Coleman et al., 1997); Spain 10-357 fg I-TEQ $\mathrm{m}^{-3}$ (Abad et al., 2007); Rome $65 \mathrm{fg} \mathrm{I-TEQ} \mathrm{m}^{-3}$ (Menichini et al., 2007); Houston $40-55 \mathrm{fg}$ I-TEQ $\mathrm{m}^{-3}$ (Correa et al., 2004)). All these results demonstrate that the PCDD/F concentrations around the iron and steel plant in this area were not high. Therefore, the impact of the steel PCDD/F emissions to the ambient air in this region should not be at a high level.

With regard to dioxin-like PCBs, the air concentrations and WHO-TEQs ranged 415-24 $622 \mathrm{fg} \mathrm{m}^{-3}$ (average $4139 \mathrm{fg} \mathrm{m}^{-3}$ ) and $1-18 \mathrm{fg} \mathrm{m}^{-3}$ (average $5 \mathrm{fg} \mathrm{m}^{-3}$ ), respectively. The steel plant site S1, S2, S3 exhibited slightly higher TEQ values than the residential site $\mathrm{S} 5$ and the background site S6. For all the measurements, dioxin-like PCBs showed lower TEQ values than those of 2,3,7,8-PCDD/ Fs. Consequently, the relative contribution of dioxin-like PCBs to the total TEQ $\left(\mathrm{TEQ}_{\mathrm{PCDD} / \mathrm{F}}+\mathrm{TEQ}_{\mathrm{PCB}}\right)$ was typically low, varying from $3.6 \%$ to $26 \%$ (average $9.5 \%$ ).

By comparing the summer and winter results, an apparent seasonal trend was found with higher PCDD/F concentrations in the winter and lower levels in the summer (Fig. 2). This seasonal trend is consistent with the results from other cities reported in the literature and the reasons have been discussed previously (Lee et al., 1999; Lohmann and Jones, 2000a). Generally, it can be explained by the intensification of diverse combustion activities, i.e. domestic heating during cold conditions. On the other hand, this seasonal trend can also be associated with the temperature effect. As can be observed in Fig. 3, PCDD/F concentrations showed significant correlation with the reciprocal of temperature (positive, $R=0.73, P<0.01$ ). Lower temperature in cold winter corresponded to higher dioxin concentrations in the air. As shown in Fig. 2, the seasonal variation of dioxin-like PCBs was also apparent, but with higher concentrations in the summer. The reason can be attributed to the significant dependence of PCBs on temperature (negative, $R=0.57, P=0.05$ ) (Fig. 3), resulting in elevated volatilization of PCBs during warm summer days (Halsall et al., 1995).

Table 1 also shows the TSP concentrations during the sampling campaign with the order of steel plant $\left(373 \mu \mathrm{g} \mathrm{m} \mathrm{m}^{-3}\right)>$ residential $\left(192 \mu \mathrm{g} \mathrm{m}^{-3}\right)>$ background area $\left(145 \mu \mathrm{g} \mathrm{m}^{-3}\right)$, indicating different contamination level of aerosol pollutions. A significant positive correlation $(R=0.78, P<0.0001)$ was found between TSP and

Table 1

Sampling volume, TSP concentration, PCDD/F and dioxin-like (dl) PCB levels during the sampling campaign.

\begin{tabular}{|c|c|c|c|c|c|c|c|c|c|c|c|c|}
\hline \multirow[t]{2}{*}{ January 12-17th 2009} & \multicolumn{2}{|c|}{ Site S1 } & \multicolumn{2}{|l|}{ Site S2 } & \multicolumn{2}{|c|}{ Site S3 } & \multicolumn{2}{|c|}{ Site S4 } & \multicolumn{2}{|c|}{ Site S5 } & \multicolumn{2}{|c|}{ Site S6 } \\
\hline & S1-1 & S1-2 & S2-1 & S2-2 & S3-1 & S3-2 & S4-1 & S4-2 & S5-1 & S5-2 & S6-1 & S6-2 \\
\hline Volume $\left(\mathrm{m}^{3}\right)$ & 278 & 290 & 284 & 270 & 256 & 269 & 298 & 322 & 341 & 286 & 295 & 233 \\
\hline $\operatorname{TSP}\left(\mu \mathrm{g} \mathrm{m}^{-3}\right)$ & 352 & 409 & 344 & 272 & 616 & 514 & 313 & 150 & 468 & 145 & 67 & 413 \\
\hline$\Sigma P C D D\left(\mathrm{fg} \mathrm{m}^{-3}\right)$ & 334 & 504 & 408 & 1459 & 1548 & 2948 & 646 & 161 & 355 & 158 & 130 & 89 \\
\hline$\Sigma P C D F\left(\mathrm{fg} \mathrm{m}^{-3}\right)$ & 632 & 1480 & 643 & 3485 & 1749 & 1193 & 2408 & 953 & 1867 & 581 & 120 & 239 \\
\hline$\Sigma \mathrm{PCDD} / \sum \mathrm{PCDF}$ & 0.53 & 0.34 & 0.63 & 0.42 & 0.89 & 2.47 & 0.27 & 0.17 & 0.19 & 0.27 & 1.08 & 0.37 \\
\hline$\Sigma \mathrm{PCDD} / \mathrm{Fs}\left(\mathrm{fg} \mathrm{m}^{-3}\right)$ & 966 & 1984 & 1051 & 4944 & 3297 & 4141 & 3054 & 1114 & 2222 & 739 & 250 & 328 \\
\hline$\Sigma \mathrm{dl}-\mathrm{PCBs}\left(\mathrm{fg} \mathrm{m}^{-3}\right)$ & 1002 & 4741 & 771 & 2734 & 3272 & 3852 & 1916 & 769 & 2549 & 859 & 1483 & 415 \\
\hline WHO-TEQ & 68 & 144 & 67 & 247 & 152 & 98 & 238 & 85 & 172 & 67 & 3 & 7 \\
\hline WHO-TEQ & 4 & 12 & 4 & 18 & 9 & 6 & 11 & 4 & 7 & 4 & 1 & 1 \\
\hline June 24-27th 2008 & S1-3 & $\mathrm{S} 1-4$ & S2-3 & - & S3-3 & S3-4 & S4-3 & S4-4 & S5-3 & S5-4 & S6-3 & S6-4 \\
\hline Volume $\left(\mathrm{m}^{3}\right)$ & 162 & 303 & 293 & - & 298 & 304 & 262 & 319 & 267 & 286 & 289 & 249 \\
\hline $\operatorname{TSP}\left(\mu \mathrm{g} \mathrm{m}^{-3}\right)$ & 313 & 326 & 205 & - & 344 & 410 & 159 & 91 & 86 & 67 & 59 & 41 \\
\hline$\Sigma P C D D\left(\mathrm{fg} \mathrm{m}^{-3}\right)$ & 58 & 492 & 137 & - & 217 & 409 & 163 & 118 & 9 & 30 & 32 & 79 \\
\hline$\Sigma P C D F\left(\mathrm{fg} \mathrm{m}^{-3}\right)$ & 485 & 1018 & 479 & - & 1135 & 1058 & 394 & 323 & 109 & 64 & 92 & 104 \\
\hline$\Sigma \mathrm{PCDD} / \sum \mathrm{PCDF}$ & 0.12 & 0.48 & 0.29 & - & 0.19 & 0.39 & 0.41 & 0.37 & 0.08 & 0.47 & 0.35 & 0.76 \\
\hline$\Sigma \mathrm{PCDD} / \mathrm{Fs}\left(\mathrm{fg} \mathrm{m}^{-3}\right)$ & 543 & 1510 & 616 & - & 1352 & 1467 & 557 & 441 & 118 & 94 & 124 & 183 \\
\hline$\Sigma$ dl-PCBs $\left(\mathrm{fg} \mathrm{m}^{-3}\right)$ & 9378 & 5215 & 24622 & - & 3387 & 4353 & 2704 & 2512 & 3656 & 3166 & 6610 & 5241 \\
\hline WHO-TEQ & 43 & 81 & 50 & - & 112 & 119 & 43 & 31 & 18 & 8 & 7 & 6 \\
\hline WHO-TEQ & 8 & 6 & 7 & & 5 & 6 & 3 & 2 & 2 & 2 & 2 & 1 \\
\hline
\end{tabular}



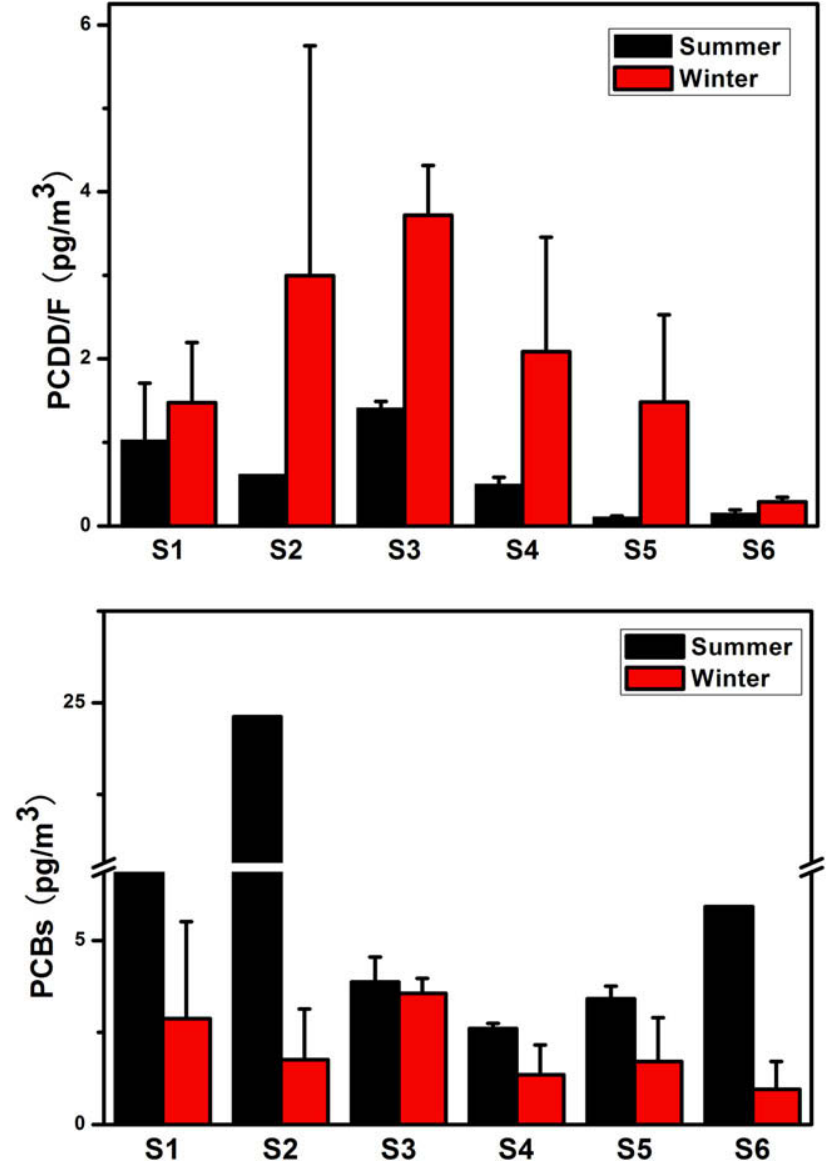

Fig. 2. Seasonal trend of PCDD/Fs and dioxin-like PCBs at the six monitoring sites.

PCDD/F concentrations, but not for PCB congeners $(P=0.32)$. This result indicates the close relation between the $\mathrm{PCDD} / \mathrm{F}$ and aerosols, as described in other studies (Chang et al., 2003). It is also consistent with the gas-particle partitioning in the ambient air, i.e. PCDD/Fs are dominantly distributed in the particles, whereas PCBs mainly exist in the gaseous phase (Lohmann et al., 2000b).

\subsection{Congener profiles}

The congener profiles in the six sampling sites were expressed in two ways; the relative contribution of individual congener to the total concentration of congeners (concentration profiles) and to the total TEQs (TEQ profiles).

The concentration profiles of PCDD/Fs are illustrated in Fig. 4. Generally, PCDD/F congeners were quite similar for the six monitoring sites. It was characterized by increasing concentrations with increasing levels of chlorination if concentrations of each homologue were summed together, similar to the world average profiles from Europe, the United States, Japan and Australia (Lohmann and Jones, 2000a). OCDF and 1,2,3,4,6,7,8-HpCDF dominated PCDD/F concentration profiles, which was responsible for relative contributions of $20 \pm 6.9 \%$ and $17 \pm 6.8 \%$, respectively. Among the seven PCDD congeners, only 1,2,3,4,6,7,8-HpCDD and OCDD were detected, while the most toxic $2,3,7,8$-TCDD was not found in any samples. Most PCDF congeners were detected in the air samples except $1,2,3,7,8,9-\mathrm{HxCDF}$ and $1,2,3,4,7,8,9-\mathrm{HpCDF}$. The PCDF concentrations were found at higher levels than PCDD groups for each measurement, with average concentrations of 456 and $896 \mathrm{fg} \mathrm{m}^{-3}$, respectively.

With respect to TEQ congener profiles, the TEQ value of PCDFs was found higher than that of PCDDs (Fig. 5). Congener 2,3,4,7,8-
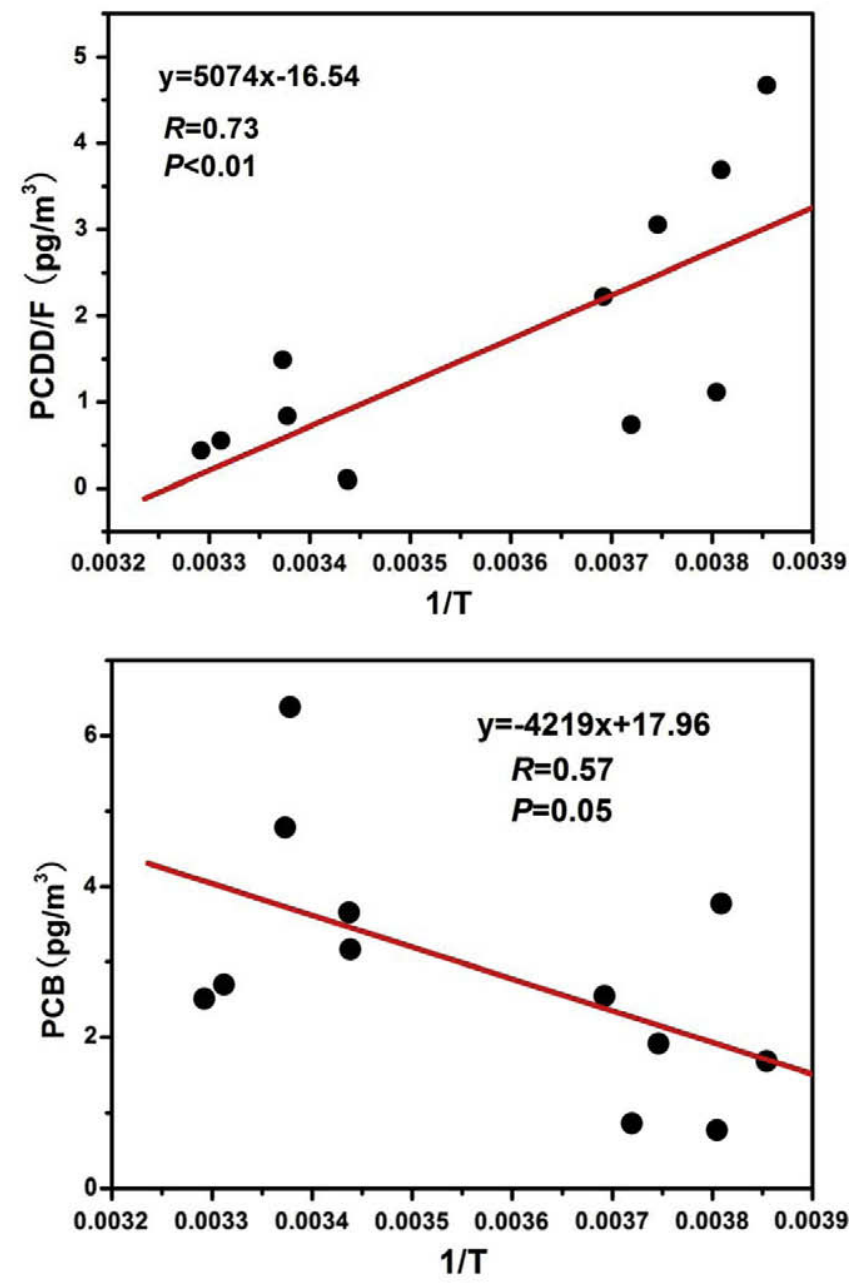

Fig. 3. Temperature dependence of $\mathrm{PCDD} / \mathrm{Fs}$ and dioxin-like PCBs.

PeCDF was the single dominant contributor to the $\mathrm{TEQ}_{\mathrm{PCDD} / \mathrm{Fs}}$, accounting for an average contribution of $53 \%$ to the toxic equivalents of $\mathrm{PCDD} / \mathrm{Fs}$. This result is also consistent with the world average ambient air (Lohmann and Jones, 2000a). The other main contributors were $1,2,3,4,7,8-\mathrm{HxCDF}, 1,2,3,6,7,8-\mathrm{HxCDF}$ and $2,3,4,6,7,8-\mathrm{HxCDF}$, accounting for average contributions of $10 \%$, $8 \%$, and $8 \%$ to the $\mathrm{TEQ}_{\mathrm{PCDD} / \mathrm{Fs}}$, respectively.

With regard to PCBs, the 12 dioxin-like congeners were detected in all air samples, with higher contribution of congeners PCB-118, PCB-105 and PCB-77, accounting for 30.6-51.9\%, $14.0-25.1 \%, 7.3-45.9 \%$ to the total concentration of PCBs. With regard to the TEQ of dioxin-like PCBs, only PCB-126 contributed dominantly to the $\mathrm{TEQ}_{\mathrm{PCBs}}$ (average contribution 91\%) due to its relatively higher toxicity equivalent factor (TEF) values in comparison with the other dioxin-like PCB congeners.

\subsection{Inhalation risk assessment}

Human dioxin exposure pathways include food ingestion, inhalation and dermal contact. Food ingestion is considered the dominant uptake route and accounts for about $95 \%$ of the total daily intakes (TDI) of dioxins (Government of Japan, 2005). Inhalation is responsible for the direct exposure to dioxins and this exposure pathway would be more important for atmospheric pollutants. Moreover, atmospheric POPs tend to partition into soil and vegetation and can bioaccumulate in the food chain, resulting in a number of indirect sources for human exposure (Nouwen et al., 2001). 


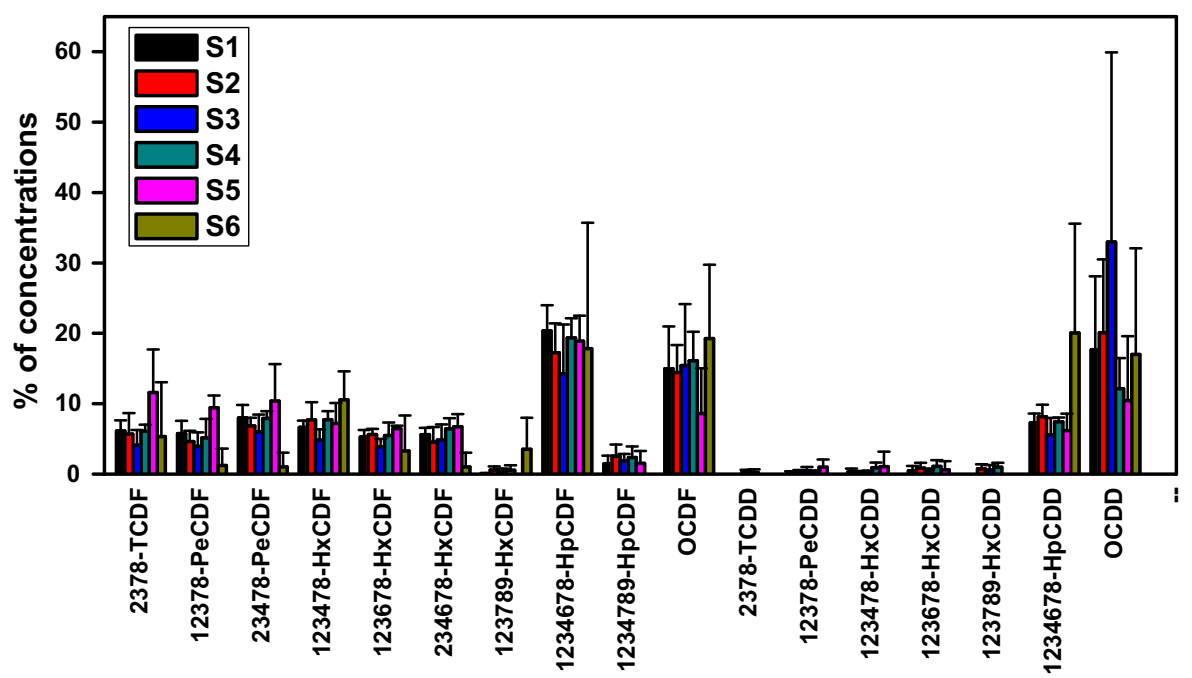

Fig. 4. Concentration profile of individual PCDD/Fs.

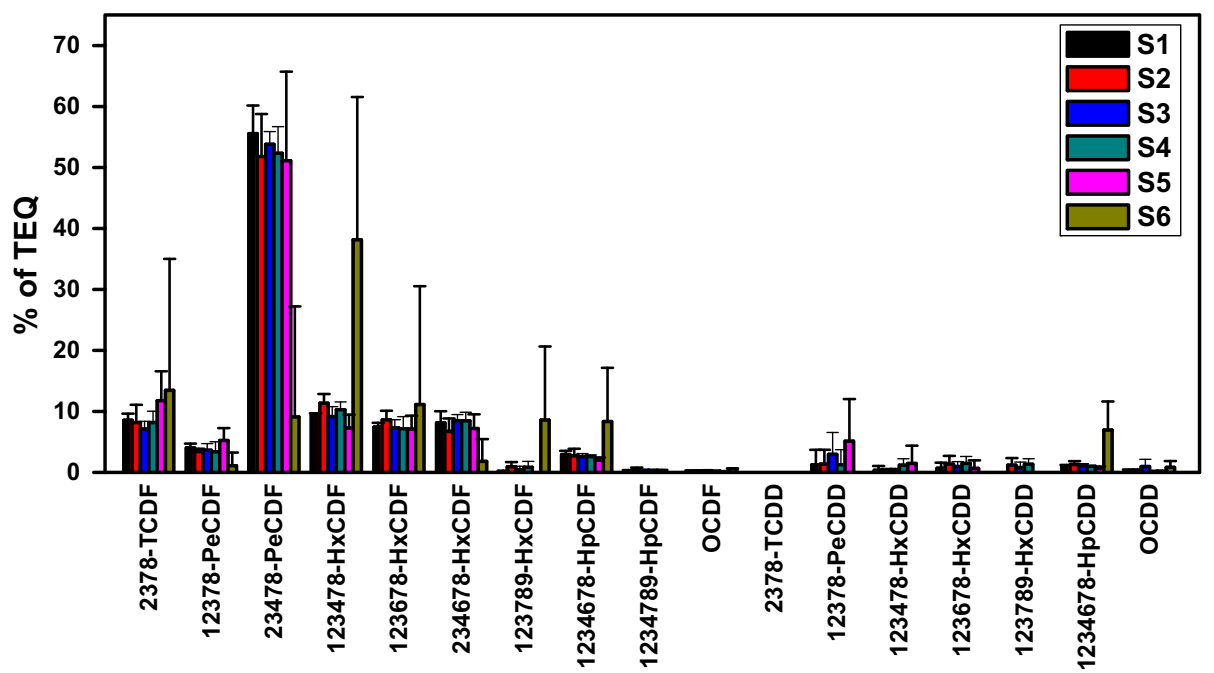

Fig. 5. Relative contribution of individual congener to the total TEQ of PCDD/Fs.

Yu et al. (2006) and Li et al. (2008b) assessed the inhalation risk of atmospheric PCDD/Fs to the residents of Guangzhou and Shanghai, but did not include dioxin-like PCBs. In this study, we calculated the inhalation exposure of PCDD/Fs and dioxin-like PCBs to the local residents around the steel plant by using the following equation (Nouwen et al., 2001):

$\operatorname{Inh}_{\mathrm{ad} / \mathrm{ch}}=V \mathrm{r}_{\mathrm{ad} / \mathrm{ch}} C_{\mathrm{air}} f_{\mathrm{r}} t_{\mathrm{f}, \mathrm{ad} / \mathrm{ch}} / W_{\mathrm{ad} / \mathrm{ch}}$

Where $\operatorname{Inh}_{\mathrm{ad} / \mathrm{ch}}$ is inhalation exposure for adults/children in fg TEQ $\mathrm{kg}^{-1} \mathrm{~d}^{-1} ; V_{\mathrm{ad} / \mathrm{ch}}$ is ventilation rate $\left(20 \mathrm{~m}^{3} \mathrm{~d}^{-1}\right.$ for adults, $7.6 \mathrm{~m}^{3} \mathrm{~d}^{-1}$ for children); $C_{\text {air }}$ is the air concentration expressed in fo TEQ $\mathrm{m}^{-3} ; \mathrm{fr}$ is the alveolar fraction retained in lung $(0.75$ for adults/children); $t_{\mathrm{f}, \mathrm{ad} / \mathrm{ch}}$ is the time fraction that adults/children spend at the impact site, which is conservatively assumed as 1 ; body weight $W_{\mathrm{ad} / \mathrm{ch}}$ is set at $70 \mathrm{~kg}$ for adults and $15 \mathrm{~kg}$ for children.

The PCDD/Fs inhalation of the steel plant workers ( $24 \mathrm{fg}$ TEQ $\mathrm{kg}^{-1} \mathrm{~d}^{-1}$ ) was found higher than the urban (22 fg TEQ $\mathrm{kg}^{-1} \mathrm{~d}^{-1}$ ), residential ( $15 \mathrm{fg}$ TEQ $\mathrm{kg}^{-1} \mathrm{~d}^{-1}$ ) and background adult residents ( $2 \mathrm{fg}$ TEQ $\mathrm{kg}^{-1} \mathrm{~d}^{-1}$ ), as summarized in Table 2 . If the PCB inhalation was taken into account, the average total inhalation was $19 \mathrm{fg}$ TEQ $\mathrm{kg}^{-1} \mathrm{~d}^{-1}$ for adults, 34 fg TEQ $\mathrm{kg}^{-1} \mathrm{~d}^{-1}$ for children, respectively. This result is lower than those in Guangzhou (Yu
Table 2

Dioxin inhalation assessment for the local residents.

\begin{tabular}{|c|c|c|c|c|}
\hline & & $\begin{array}{l}\text { PCDD/Fs } \\
\text { inhalation } \\
\left(\text { fg TEQ } \mathrm{kg}^{-1} \mathrm{~d}^{-1}\right)\end{array}$ & $\begin{array}{l}\text { PCBs inhalation } \\
\left(\text { fg TEQ } \mathrm{kg}^{-1} \mathrm{~d}^{-1}\right)\end{array}$ & $\begin{array}{l}\text { Total inhalation } \\
\left(\text { fg TEQ } \mathrm{kg}^{-1} \mathrm{~d}^{-1}\right)\end{array}$ \\
\hline \multirow[t]{2}{*}{ S1 } & Adult & 18 & 1.6 & 20 \\
\hline & Children & 32 & 2.9 & 35 \\
\hline \multirow[t]{2}{*}{ S2 } & Adult & 26 & 2.1 & 28 \\
\hline & Children & 46 & 3.7 & 50 \\
\hline \multirow[t]{2}{*}{ S3 } & Adult & 26 & 1.4 & 27 \\
\hline & Children & 46 & 2.5 & 49 \\
\hline \multirow[t]{2}{*}{ S4 } & Adult & 21 & 1.1 & 22 \\
\hline & Children & 38 & 1.9 & 40 \\
\hline \multirow[t]{2}{*}{ S5 } & Adult & 14 & 0.9 & 15 \\
\hline & Children & 25 & 1.5 & 27 \\
\hline \multirow[t]{2}{*}{ S6 } & Adult & 1.3 & 0.2 & 1.5 \\
\hline & Children & 2.3 & 0.4 & 2.7 \\
\hline \multirow[t]{2}{*}{ Average } & Adult & 18 & 1.2 & 19 \\
\hline & Children & 32 & 2.2 & 34 \\
\hline
\end{tabular}

et al., 2006) and Shanghai (Li et al., 2008b). The contribution of PCB to the total inhalation was small compared to PCDD/Fs, varying from $4.9 \%$ to $13.3 \%$. It should be noted that children were at 
higher risk of exposure to dioxins compared to the adults according to the inhalation assessment of this study.

\section{Acknowledgements}

This work was jointly supported by the Ministry of Environmental Protection of China for the Project of Toxic Substances in the Atmosphere and Their Effect to the Soil, the National Hi-tech Research and Development Program of China (2007AA061601) and the National Natural Science Foundation of China (20907059, 20777079).

\section{Appendix A. Supplementary material}

Supplementary data associated with this article can be found, in the online version, at doi:10.1016/j.chemosphere.2010.01.061.

\section{References}

Abad, E., Martínez, K., Gustems, L., Gómez, R., Guinart, X., Hernández, I., Rivera, J., 2007. Ten years measuring PCDDs/PCDFs in ambient air of Catalonia (Spain). Chemosphere 67, 1709-1714.

Anderson, D.R., Fisher, R., 2002. Sources of dioxins in the United Kingdom: the steel industry and other sources. Chemosphere 46, 371-381.

Aries, E., Anderson, D.R., Fisher, R., Fray, T.A.T., Hemfrey, D., 2006. PCDD/F and "dioxin-like" PCB emissions from iron ore sintering plants in the UK. Chemosphere 65, 1470-1480.

Chang, M.B., Weng, Y.M., Lee, T.Y., Chen, Y.W., Chang, S.H., Chi, K.H., 2003. Sampling and analysis of ambient dioxins in Northern Taiwan. Chemosphere 51, 11031110.

Coleman, P.J., Lee, R.G.M., Alcock, R.E., Jones, K.C., 1997. Observations on PAH, PCB and PCDD/F trends in UK urban air, 1991-1995. Environ. Sci. Technol. 31, 21202124.

Correa, O., Rifai, H., Raun, L., Suarez, M., Koenig, L., 2004. Concentrations and vaporparticle partitioning of polychlorinated dibenzo-p-dioxins and dibenzofurans in ambient air of Houston, TX. Atmos. Environ. 38, 6687-6699.

Fiedler, H., 1996. Sources of PCDD/F and impact on the environment. Chemosphere $32,55-64$.

Government of Japan. Information Brochure Dioxins, 2005. <http://www.env.go.jp/ en/chemi/dioxins/brochure2005.pdf $>$.

Halsall, C.J., Lee, R.G.M., Coleman, P.J., Burnett, V., Harding-Jones, P., Jones, K.C., 1995. PCBs in UK urban air. Environ. Sci. Technol. 29, 2368-2376.

Kouimtzis, T.H., Samara, C., Voutsa, D., Balafoutis, C.H., Müller, L., 2002. PCDD/Fs and PCBs in air borne particulate matter of the greater Thessaloniki area, N. Greece. Chemosphere 47, 193-205.

Lee, R.G., Green, N.J., Lohmann, R., Jones, K.C., 1999. Seasonal, anthropogenic, air mass, and meteorological influences on the atmospheric concentrations of polychlorinated dibenzo- $p$-dioxins and dibenzofurans (PCDD/Fs): evidence for the importance of diffuse combustion sources. Environ. Sci. Technol. 33, 28642871.
Li, Y.M., Jiang, G.B., Wang, Y.W., Cai, Z.W., Zhang, Q.H., 2008a. Concentrations, profiles and gas-particle partitioning of polychlorinated dibenzo-p-dioxins and dibenzo-furans in the ambient air of Beijing, China. Atmos. Environ. 42, 20372047.

Li, H.R., Feng, J.L., Sheng, G.Y., Lu, S.L., Fu, J.M., Peng, P.A., Man, R., 2008b. The PCDD/F and $\mathrm{PBDD} / \mathrm{F}$ pollution in the ambient atmosphere of Shanghai, China. Chemosphere 70, 576-583.

Lohmann, R., Jones, K.C., 2000a. Dioxins and furans in air and deposition: a review of levels, behavior and processes. Sci. Total Environ. 219, 53-81.

Lohmann, R., Harner, T., Thomas, G.O., Jones, K.C., 2000b. A comparative study of the gas-particle partitioning of PCDD/Fs, PCBs and PAH. Environ. Sci. Technol. 34, 4943-4951.

Menichini, E., Iacovella, N., Monfredini, F., Turrio-Baldassarri, L., 2007. Atmospheric pollution by PAHs, PCDD/Fs and PCBs simultaneously collected at a regional background site in central Italy and at an urban site in Rome. Chemosphere 69, 422-434.

Nouwen, J., Cornelis, C., De Fré, R., Wevers, M., Viaene, R., Mensink, C., Patyn, J., Verschaeve, L., Hooghe, R., Maes, A., Collier, M., Schoeters, G., van Cleuvenbergen, R., Geuzens, P., 2001. Health risk assessment of dioxin emissions from municipal waste incinerators: the Neerlandquarter (Wilrijk, Belgium). Chemosphere 43, 909-923.

Park, J.S., Kim, J.G., 2002. Regional measurements of PCDD/PCDF concentrations in Korean atmosphere and comparison with gas-particle partitioning models. Chemosphere 49, 755-764.

Quaß, U., Fermann, M., Bröker, G., 2000. Steps towards a European dioxin emission inventory. Chemosphere 40, 1125-1129.

Quaß, U., Fermann, M., Bröker, G., 2004. The European dioxin air emission inventory project-final results. Chemosphere 54, 1319-1327.

Sin, D.W.M., Choi, J.Y.Y., Louie, P.K.K., 2002. A study of polychlorinated dibenzo-pdioxins and dibenzofurans in the atmosphere of Hong Kong. Chemosphere 47, 647-653.

UNEP, Stockholm Convention on Persistent Organic Pollutants (POPs), 2001. <http:// www.pops.int>.

US EPA, Method 1613. Revision B: Tetra-Through Octa-Chlorinated Dioxins and Furans by Isotope Dilution HRGC/HRMS in Guidelines Establishing Test Procedure for the Analysis of Pollutants; EPA Method 1613; Final Rule, 40 CFR Part 136, 1997.

US EPA, Method TO 9A. Determination of Polychlorinated, Polybrominated and Brominated/Chlorinated Dibenzo-p-Dioxins and Dibenzofurans in the Ambient Air, EPA/625/R-96/010b, 1999a.

US EPA, Method 1668, Revision A: Chlorinated Biphenyl Congeners in Water, Soil, Sediment, and Tissue by HRGC/HRMS, EPA-821-R-00-002, 1999b.

Van Bavel, B., 2005. Final Report Tenth Round of the International Intercalibration Study. Workgroup International Intercalibration Studies, Sweden.

Xu, M.X., Yan, J.H., Lu, S.Y., Li, X.D., Chen, T., Ni, M.J., Dai, H.F., Wang, F., Cen, K.F., 2009. Concentrations, profiles and sources of atmospheric PCDD/Fs near a municipal solid waste incinerator in Eastern China. Environ. Sci. Technol. 43, 1023-1029.

Yu, L.P., Mai, B.X., Meng, X.Z., Bi, X.H., Sheng, G.Y., Fu, J.M., Peng, P.A., 2006. Particlebound polychlorinated dibenzo-p-dioxins and dibenzo-furans in the atmosphere of Guangzhou. China Atmos. Environ. 40, 96-108.

Zhu, J.X., Hirai, Y., Sakai, S., Zheng, M.H., 2008. Potential source and emission analysis of polychlorinated dibenzo-p-dioxins and polychlorinated dibenzofurans in China. Chemosphere 73, S72-S77. 